\title{
Can they be compared?
}

- An essay on the historical development of welfare systems in Russia and Norway 


\begin{abstract}
This essay concentrates on the social modernization that took place in Russia and Norway during the period from the late 19th to the early 21 st century by examining the origins and the subsequent development of their welfare systems, including the social legislation passed. The focus is on the professional assistance provided and the specialized workers engaged in social care for the underprivileged sections of the population. All this is analyzed in the context of the economic and political development of the two states, attempts to bring about integration made during international congresses and discussions within and outside the countries concerning social policy. The specialists improved the situation of the poor to a certain extent and pulled their weight in the formation of a Russian and Norwegian model of welfare peculiar to these countries and the regions close to the border between them. In this article, special attention is paid to Russian and Norwegian peculiarities in terms of the training given to Russian and Norwegian social workers during the last 200 years. It also contains information about the formation of a philanthropic movement in Russia and Norway and about the cooperation between the state-sustained charitable institutions. The essay demonstrates that the experience in the Russian and Norwegian North is a good example of productive forces on both sides of the border striving to retain the tradition of interaction up to 1917 in the field of social protection, by providing neighbourly assistance.
\end{abstract}

As everyone knows, Russia and Norway are neighboring countries with a long history of interaction in economic, political and cultural spheres. But as yet, we do not know very much about the features of and interaction between the welfare systems of these two countries. I will try to concentrate on just a few of the features of the creation of a welfare system in Russia and Norway, not only as neighboring countries, but also as countries that have been in constant trade, political and social contacts with one another for many years.

\title{
The preconditions and origin of professional social assistance
}

The modernization of the welfare system that took place in the second half of the 19th and the 20th century led to worldwide changes in the provision of social assistance to various sectors of the population both in Russia and in Norway, and laid the foundations for the application of an effective social policy for decades to come. The process of welfare modernization in Russia and Norway can be considered to have taken place over three main periods, covering a period of about 200 years, with similar stages being identifiable in the two countries.

- $\quad$ Formation and start - 1814 -1917 (about 100 years);

- Development and stabilization - 1918 to the 1980s (about 70 years);

- New reformation - 1990s to the early years of 2000 (about 20 years).

The development and the changes that took place in each of the respective countries were not isolated from the other spheres of activity. They were carried out in the context of the economic, political and social conditions that were themselves influenced by traditions, national preferences and aspirations. Among them, there were some common aspects, like the agricultural character of the economy until about 1850, the majority of the population being comprised of peasants, the importance of community and the role of the church in everyday life. At the same time, the two states had some differences that were also influential for welfare. Amongst these, we can underline the work conducted by parliament and the constitution in Norway that had begun to influence the social order and social legislation from 1814. In Russia, a national assembly only appeared 92 years later, in 1906. During the years prior to 1906, both the tsarist power institutions and the public organizations tried to construct a welfare system and introduce legislation addressing social wellbeing. The legislation aimed to support the most needy groups of the population, to construct and help in developing the state-public system of assistance, and to support the private and church initiatives in the provision of social care. 
Between 1860-1870, industrialization took off in both countries, as a result of which, the social conditions of the population as a whole worsened dramatically. In both Russia and Norway, the necessity of implementing change at a social level was recognized. Thus, the underlying conditions for the development of the social policy in the two countries resembled one another closely.

Table 1: Political and socio-economic features of the development of Russia and Norway (1814-1917)

\begin{tabular}{|l|l|l|}
\hline Parameters & Norway & Russia \\
\hline Creation of a national assembly & 1814 & 1906 \\
\hline First constitution & 1814 & 1906 \\
\hline $\begin{array}{l}\text { The beginning of market } \\
\text { modernization }\end{array}$ & $1850-1860 \mathrm{~s}$ & $1860 \mathrm{~s}$ \\
\hline First political parties & $1880 \mathrm{~s}$ & $1890 \mathrm{~s}$ \\
\hline The first social legislation & $1820 \mathrm{~s}$ & $1860 \mathrm{~s}$ \\
\hline $\begin{array}{l}\text { Formation of the charity } \\
\text { movement }\end{array}$ & $1860 \mathrm{~s}$ & $1830 \mathrm{~s}$ \\
\hline $\begin{array}{l}\text { The first social work course or } \\
\text { school }\end{array}$ & 1920 & $1830 \mathrm{~s}$ \\
\hline
\end{tabular}

When analyzing the particularities of the movement towards the introduction of a system of effective social care in Russia in the second half of the 19th century, it is obvious that the difference between the Russian model and the one that existed in Norway, was the difference in the time at which the organizational and legislative changes commenced, and forces in society, including the level of welfare that they envisaged. In Russia, the tsar and the Department of Public Care, which was subordinate to him, determined the policies in the social sphere. From 1775, this department rendered assistance to the most needy civil servants, widows, war veterans and children. However, the greater part of the population, which also lived in poverty, received no such help. In parallel with the official social institutions of the state, those members of the tsar's family, nobles and merchants, who wanted to show compassion, as taught by the Russian-orthodox church, provided help privately.

Turning to Norway, in the middle of the 19th century, the necessity of establishing an effective system of social protection became increasingly pressing, as a result of which politicians searched for ways of developing the social sphere. The situation in Norway in this period was less complicated than in Russia. After the Crimean War, a crisis arose in the central regions of Norway, which depended almost entirely on their agricultural production, partly because of economic underdevelopment, and partly as a result of increasing competition from imported grain. Right up to the 1880s, Norway lagged behind from the point of view of agricultural reform and continued to be a largely agrarian economy, as it struggled to build its economic development on a sound industrial base. Thus in Norway, like in Russia, the poverty and poor welfare conditions that accompanied the crisis were a result of the continued backwardness of the economy.

However, in contrast to the situation in Russia, debates took place at a national level in this period in Norway, to consider how the situation in the country could be improved. The parliament was a highly representative legislative organ in the political system of the country, and it was far from being under the complete control of the king. Doubtless this made it easier, in many ways, for Norway to get out of the crisis. As for Russia, debates took place at approximately the same time as in Norway, in the period from 1860 to the 1890 s, with the members of charitable organizations and the authorities discussing better ways to promote social activity in the country. 
It is also worth emphasizing that three groups were active in forming the social policies in Norway, and are still active there today: the liberal professions, like doctors, economists and civil servants working in the new institution of social protection; groups who supported the reform, including philanthropic institutions and the women's movement; and, thirdly, groups connected with politics, political parties, trade unions, and trade and industrial associations. These three groups started to act as a unified body in their aspirations to review the conception and legislative base of the social policies, and in their pushing for the use of financial resources from the growth of the economy to meet social needs. They also made a great step forwards by abolishing the nobility in an act dating to 1821 .

In Norway, therefore, a system of assurance was introduced at the beginning of the 20th century to cover cases of injury sustained in production, and to provide for old age, illness and unemployment. Thus, issues connected with sudden loss of income were solved through legislation, as additions to the Poor Law, which had been in force since the early 1860s. At this time, discussions commenced to determine policies aimed at the protection of children, especially from the poor classes. The system of health care was officially taken under state control and significantly improved.

In Russia from the 1860s to the 1890s, progressive members of the community, \#consisting of members of the intelligentsia or of charitable associations, and employers in social institutions stressed that it was essential to transfer charitable institutions from the state to rural and urban local authorities. The Commission for Reviewing Legislation on Social Care, established by order of Tsar Alexander III (1881-1894), and headed up by K.K. Grot, was forced to agree with this position in the period 1892-1897.

As a consequence, in Russia, charity became a state-public system where the state fulfilled a minor role as controller and organizer of the social policies, leaving most of the duties to be performed by public institutions (societies, unions, etc.) organized and supported greatly by the citizens. Moreover, it is possible to say that from the 1860 s until 1914, a great charitable (public and mostly independent) movement grew up in Russia. But it is evident that in Norway the state authorities and public forces were more active, unified and accepted greater responsibility, something which probably assisted in forming the identity and the truly social long-term direction of the politics of this Nordic country.

In Russia, on the other hand, the local organs of rural and urban self-government, consisting of municipalities (gorodskie dumy) and zemstvo-institutions (the public authorities in small towns and villages), and a radically enlarged charity movement began to pay particular attention to housing, the prevention of destitution, criminality and to other socially hazardous phenomena. Organized forms of provision appeared, such as the weekly or monthly issue of allowances in the form of money, food, clothes and footwear; teaching literacy and trades to adolescents and women (including those who had 'fallen'); and involving vagrants, the poor, beggars and the unemployed in public works. Indeed, the declared principle of activating the socially deprived was applied, which meant returning them to normal working life through the organization of 'employment assistance', as a special part of social help. Coincidentally, there were also active municipalities in Norway that helped to decide some important problems in Norway. Thus, there were parallel processes in Norway and Russia turning the municipalities into one of the main stays of social assistance.

One of the most effective means of interaction open to Russia and Norway for the provision of social help was their ongoing participation in various international meetings and discussions. There was an almost annual dialogue, not only between professionals involved in the provision of assistance or philanthropists, in the early days, but also including statesmen, businessmen and scientists. Meetings could take place in Europe in the form of the international congresses. 
Table 2: International congresses involving the participation of Norway and Russia (1856-1917)

\begin{tabular}{|l|l|l|}
\hline Title of the congress & $\begin{array}{l}\text { Period over which the congress } \\
\text { was conducted }\end{array}$ & The number of congresses \\
\hline $\begin{array}{l}\text { Public and private assistance, } \\
\text { and charity }\end{array}$ & $1856-1911$ & 8 \\
\hline Criminal and penitentiary system & $1872-1910$ & 8 \\
\hline The deaf-and-dumb and blind & $1878-1910$ & 6 \\
\hline $\begin{array}{l}\text { Patronage of the poor, children, } \\
\text { etc. }\end{array}$ & $1878-1911$ & 6 \\
\hline $\begin{array}{l}\text { Unfortunate accidents: their } \\
\text { production and insurance }\end{array}$ & $1889-1908$ & 7 \\
\hline $\begin{array}{l}\text { Childhood security, protection, } \\
\text { and the fight against infant death }\end{array}$ & $1890-1913$ & 6 \\
\hline Family upbringing & $1905-1910$ & 3 \\
\hline Physical education and sport & $1905-1906$ & 2 \\
\hline Public education & 1907 & 1 \\
\hline
\end{tabular}

\section{Interrelation of social welfare models}

International congresses concerning charity, the state, and public and private assistance offered the most wide-reaching possibilities for interaction between Russia and Norway. Between 1856 and 1911, eight congresses provided participants with an opportunity to discuss social problems with each other. Norway took part in all the meetings, the Russian representatives began to participate actively (rather than just attending as invited guests) in 1900, starting with the sixth congress.

At the third of the congresses, which happened to take place in London in 1862, one of the first reports was made by Eilert Sundt and was devoted to Norway and, in particular, to its education system .

At the VIIth International Congress concerning public and private assistance, which took place in Milan in 1906, amongst other things, the issue of foreigners was discussed. The basic issue concerned the simplification of movement between countries and providing deprived people with a job, people who, inevitably, aspired for the best life possible in any of the countries to which they could move. Such interrelations between the countries and the general approaches put forward were based on principles of reciprocity, through granting care to poor foreigners in the same manner as that provided to the nation's own citizens .

Four years later, in August 1910, practically simultaneously with the First Congress of Russian Figures on Public and Private Assistance, problems associated with the difficulty of training social workers were discussed. This dialogue took place in Copenhagen at the VIIIth International Congress. In the final resolution, a motion was supported stating that the governments should render all assistance of the poor, the sick, and of orphans to professional trustees of the poor. For this purpose, it was recommended that schools dedicated to training people in the provision of assistance be created.

In addition, the congress considered the status of women within the system offering the provision of social assistance. From this time onwards, women could occupy administrative posts equal to those of men in establishments providing assistance; this had previously been problematic. For the first time, their opinion was also acknowledged to be of importance for the organization of assistance. This decision was one of the important influences on the official position of the authorities of different countries, who determined to attract women into 
social policy in 20th century, a policy that starting a tradition that endures to this day. But in Russia, until recently, women were tremendously active in the provision of care rather than in the decision-making that determined how this was achieved.

In 1910, each of the countries concerned, including Norway and Russia, had general reports prepared about the development of social help in their country. These reports are still relevant today, and could continue to be of use in the formation of social policy in each country when considering traditions, national features and past experience, and for promoting pan-European initiatives and priorities.

In addition to the congresses concerning charity, the state, and public and private assistance in the second half of the 19th and beginning of the 20th century, Russia and Norway also entered into contact with one another at international meetings like the Congress on Affairs of the Penitentiary System, the Congress on Affairs of the Deaf-and-dumb and Blind, the Congress of Insurance, and the Congress of Home Nursing for Children etc.

\section{The beginning of social work education}

In a period of reformatory processes affecting all levels of life and society, conducted under the influence of international strategies, Russia acquired a certain amount of the experience necessary for training social workers. The societies and institutions responsible for undertaking this training in Russia (1840-1917) were the following:

- charitable societies and institutions, which acted under the protection of largescale state-public associations, and were supported by the tsarist authorities (i.e., the Institution of Empress Maria, the Imperial Philanthropic Society and the Russian Red Cross Society);

- $\quad$ separate, independent charitable societies;

- rural and urban social institutions in the provinces;

- $\quad$ public and private non-state educational institutions (the private high school named in honour of P.F. Lesgaft (1907), the Moscow Urban People's University named in honour of A.L. Shaniavskiy (1908), the Pedagogical Institute named in honour of P.G. Shelaputin (1911), the Psycho-neurological Institute (1907), and others).

While there were six courses in 1861 where introductory or full-scale preparation of professional social workers took place, in 1900-1905 the number of such institutions had increased to about 200. Thus, in 1861 about 150 charitable sisters and brothers took part in such courses given by the Red Cross, the Institution of Empress Maria and others, but in 1905, the number of graduates trained by various charitable organizations numbered approximately 60,000 . Even this was far from enough, though, since for every graduate of the training program, on average there were more than 2000 citizens who required special social assistance.

The experience of training social workers in Russia advanced principally in two socialhumanitarian areas, pedagogy and medicine. At about this time, between 1900 and 1910, a third aspect was added in the humanitarian and natural science education, which was generally lacking in society: In Norway, right from the start, courses were given offering training

Table 3: Social work courses and schools in Norway and Russia (1830 -2000)

\begin{tabular}{|l|l|l|l|l|l|l|l|}
\hline Country & $\mathbf{1 8 3 0 s}$ & $\mathbf{1 8 6 0 s}$ & $\mathbf{1 8 9 0 s}$ & $\mathbf{1 9 2 0 s}$ & $\mathbf{1 9 5 0 s}$ & $\mathbf{1 9 8 0 s}$ & $\mathbf{2 0 0 0 s}$ \\
\hline Russia & 1 & 6 & 200 & 0 & 0 & 0 & 130 \\
\hline Norway & 0 & 0 & 0 & 1 & 2 & 5 & 12 \\
\hline
\end{tabular}


on psychological issues and work experience in society working with clients, which is a sharp contrast to the training available in Russia. Norway was influenced by international experience, but the first school for social workers was only founded more than about 85 years after the first one in Russia, in 1920. But Norwegian identity was similar to that in Russia where the struggle for women to obtain social and professional rights was concerned. Moreover, in the early of the 1900s, social work was perceived to offer women the opportunity to engage in active employment and to obtain a certain prestige in Norway. Therefore, social work training was, in the first instance, provided for woman from middle and upper classes. The same is true of Russia. However it is necessary to notice that, in Russia, the establishment of courses and training schools pursued the more practical aims of training for the sake of providing qualitative help to poor people on a new level.

All in all, philanthropy in Russia in the second half of the 19th and early 20th century became a wide public movement, a mechanism for cooperation between society and state, introducing practical forms of social assistance, that were more efficient than the aid provided by the state.

Thus, by 1917, in contrast to Norway, Russia had a considerable amount of experience in training. However during the Soviet period, the educational structures created before revolution, began to be substituted by humanitarian or medical faculties or institutes. So, twice the responsibility was given to the doctors, teachers, and trade-union leaders prepared by the social work schools. They carried out their formal duties, but at the same time were compelled to take on social work. Despite being so important for the country, the role of a social worker did not exist in Russia until the 1990 as a profession. But after the 1920s, Norway introduced social work as a separate education and a special sphere of employment, thereby managing to accumulate 70 years of experience in, for example, devising programs, developing training techniques, and in applying the knowledge of experts.

Meanwhile both Russia and Norway had built up a significant body of experience by the end of the 20th century. Russia had accumulated an ability to integrate really interconnected spheres of employment, and to provide disinterested help to the poor, so necessary in social work. Besides which, in the Soviet era, work involved teenagers in labour camps, children in children's homes, adults in public works, families, etc. All this is extremely interesting today, as are other forms of socio-pedagogical or socio-medical activity. In Norway during the period from 1920 to the 1980s, one strategy adopted was the use of experts to provide assistance to citizens, and another was strengthening the rights of women at the expense of the given activity. These achievements and the experience gained are still important today.

\section{The transformation of social policy in the 1920s}

For about 70 years from $1917 / 8$ and up to the beginning to the early 1990s, Russia had real break from the international dialogue, it did not participate in discussions and knew little about social policy in other countries, or about what was going on abroad. During this period, as a result of the absence of interaction, Russian social policy developed in isolation, with no interesting experiences from Russia being reported abroad, or vice versa, and the two countries being unaware of how each other's social care systems worked.

Meanwhile, Norway continued to search for and approbate effective ways of carrying out its social policy. Russia was distanced from the Norwegian experience, and in many ways it was at the front line after the 1920s-1930s. But Russia did not lose time in the Soviet years, instead it searched for and tried out some different, and interesting things in the social sphere, just like Norway.

The Soviet state started to take responsibility upon itself for the care of all members of 
the various categories of the population, and began to move gradually from the principle of individualization in the provision of social assistance to a centralized and rigid distribution of benefits. Thus, the state took on a systematic and more organized responsibility for the social wellbeing of its citizens, which, in turn, became an integral part of the construction of a new Soviet society. Nowadays some historians regard the events that occurred in the Soviet period of Russian history as one of the most ambitious projects to build a pan-European "social" or "welfare state", the idea of which had originated in the period of the Enlightenment.

Consequently, despite a series of seemingly similar social and economic conditions that gave rise to fundamental social transformations, throughout the majority of the 20th century, social policy in Russia and Norway took on their own peculiarities in the question of social welfare. But still, Russia had succeeded to a certain extent in being integrated into the European socio-political system, and if it had chosen a gradual modernization instead of revolution in 1917, this could have led to development in the same direction as that taken by the Nordic countries in the long run.

\section{The epoch of new social reforms and order}

In the early 1990s a period of reorganization of the political, economic and social systems began in Russia and in Norway. In Russia, the years of transition from the Soviet planned way of conducting social security for the majority of citizens led to reform of the provision social protection. In Norway, the 1990s became a period notable for changes in the structure of social care, education and public health services, in the migratory policy, connected with economy growth.

Certainly, by the end of 20th century, Norway had achieved much in terms of ensuring the wellbeing of its elderly citizens, and of children, women, etc. Large budgets had been allocated for the support of various categories of citizens, and their rights were protected, their security ensured. And now the country is fulfilling its social responsibilities. The private and state organizations created are engaged in social activity. A state strategy to perfect the system that developed and became stable during the 20th century has been adopted. However, during the last decade, Norway has been shown to have inadequate provisions for dealing with certain social problems concerning the elderly, migrants and the jobless, as indeed, have various other states.

In Russia a similar picture emerged during recent decades. As a result of post-Soviet reforms, new centers were set up to help with sick children, the elderly and others. Departments of social work and public organizations became more active and the organizations popped up in rapid succession. Meanwhile, unlike Norway, innovations have appeared in Russia in less than 17-20 years, so it can be expected that many of these will be short-term measures, and it is inevitable that more development will be required. Besides, unlike Norway, the level of financing in the social sphere in Russia remains inadequate. This means that Russia is developing its new social services very rapidly, by charging through most of the period of development that took Norway about 100 years in just a couple of decades.

In Russia, the state shoulders almost all the burden for taking care of the poor, and especially for those who had become destitute over the years leading up to the 1990s. In Norway the strategy is almost the same, but private companies are actively involved in the provision of care, too. The Russian private social services are not yet as well-developed as those in Norway, but the system is different, and those that are in existence operate in conjunction with state institutions. Furthermore, in Russia, the employment of professional social workers is not particularly efficiently organized, unlike in Norway.

Meanwhile Russia is distinguished from Norway in that it had and still has a unique feature, 
which is that, above all, its social care is governed by Christian mercy accumulated over past centuries (but which was partly forgotten during the Soviet era), and children experience an upbringing in the tradition of showing warm compassion towards those in need. Over at least the last two centuries, Norwegians felt social responsibility to be their basic Christian duty and instigated a policy of full protection provided by the state.

These feelings of compassion and mercy are so strong in Russia that, despite powerful influence in the Soviet era, the full charitable impulses could not destroy the benevolence of the public organizations, and of private persons, which took place in the country at various times. Certainly, the existence of public organizations in Russia, in the past and present, whose members nobody forces to give soul for the blessing of whose benefactors are free to choose, provides proof of the display of this special quality of mercy through allowing the social services in Russia to make a strong come back and to have made great steps forward at the beginning of the 21 st century.

\section{The construction of social work training}

At the beginning of the 1990s the Russian Ministry of Labour and Social Development started working on the theoretical and practical bases of professional social work with experts in higher education, and others. This has included modifying the form of courses, the direction they are intended to take, and the bases the preparatory courses offer, as well as the list of professional skills required to become a fully certified social worker, but, unfortunately, the experience gained in the last few decades was often ignored. Thus, the basic approaches for appearing the faculties of social work were connected both with the necessity of the social institutions, and the regions in the training staff in the sphere of social assistance.

Since the second half of the 1990s, full-time attendance at social work faculties in the institutions of higher learning has become the norm in Russia. The educational institutions that have started training social workers can be classified according to the type of school providing the education; the number of institutions involved in each case is given in parentheses .

- $\quad$ Classical universities (12-14)

- Medical universities (3)

- Teacher training colleges and universities (80-82)

- Military academies and schools (5-7)

- Engineering, tourism and others (16-17)

- Total (116-123).

Table 4: The dynamics of social work training in the full-time in faculties in Russia (1991-2007)

\begin{tabular}{|l|l|l|l|l|}
\hline Parameters & 1991 & 1995 & $\mathbf{2 0 0 0}$ & $\mathbf{2 0 0 7}$ \\
\hline $\begin{array}{l}\text { Number of schools of higher } \\
\text { education (universities) }\end{array}$ & $10-15$ & 60 & 110 & 130 \\
\hline The number of students entering & $350-400$ & 860 & 4400 & About 6000 \\
\hline $\begin{array}{l}\text { The number of graduating } \\
\text { students }\end{array}$ & - & 400 & $3000-3200$ & About 5200 \\
\hline
\end{tabular}

The majority of the institutes are organized under the wings of teacher training institutes, thereby proving that these institutes were oriented towards being training schools for social workers, rather than purely academic institutes. What is more, placing the emphasis on the socio-pedagogical orientation of education was considered to be in the spirit of the Russian historical traditions of the early 20th century, and which resumed their natural course at the end of the 20th century. Essentially, the institutions of higher learning took it upon themselves to organize social work in cities and for the regions, and the students and teachers have assumed the role of professional volunteers. As a matter of fact, the volunteer activities resulted in a charitable foundation for the veterans, the disabled and other groups of citizens. 
Research into the sphere of social work has developed concurrently with the realization of the educational method of providing social workers. During the 1990s, research schools were set up at the Altai State University, the Saratov State Technological University, the Moscow Youth Institute and other educational institutions. A center for the application of scientific methods was opened on the campus of the Russian State Social University, which began conducting research into the standardization of social work education.

If there were 21 universities that had opened special social work faculties in Russia in 1992, at the end of 2007 their number had increased to 130 . Furthermore, reference to publications on statistical data show, that, in 1991-1992 higher educational institutions preparing experts in social work were active in 17 areas of the Russian Federation, by the end of 2007, social work faculties have already been opened in 66 regions (the number of the areas in Russia now is 85 ).

In Norway it has been possible to open 12 colleges for a professional training where about 700-713 students are trained annually. Students are trained for three years, meanwhile in Russia they follow a five year program. However, in Norway, programs in a variety of subjects can coincide with studies of the Russian language, which allows one to consider the prospect of further integration between these two countries and an increase in their understanding of one another. Norway and Russia were among the first countries to have embarked on a rapprochement since the Soviet era commenced, or, in reality, one can consider them to have launched themselves into a continuation of the integration that had been suspended at the beginning of the 20th century. The most active in this process, or the pilot territory, has been the Northwest of Russia.

\section{The role of the north in the development of the current social policy}

Changes have been evident in the north since the 1990s where the development of priorities in social policy are concerned, enabling social care to pass from principles based on the provision of social support to the social protection of each individual. The priorities have been reflected in a document entitled the Concept of the Development of the Social Service of the Population in the Russian Federation, as accepted in August, 1993.

In Russia in the last decade, including the north, of course, the laws governing pensions, health care and medical services, education, and the social care of children, the unemployed and the sick were thoroughly updated. A revision took place of the system of assistive services (including home nursing, the advisory services, social rehabilitation, etc.). Specialists in social work or socionoms appeared. In addition, since 2006, work has started on nationwide projects on "education", "medicine" and "accessible habitation". At the beginning of 2008, they had already brought about some positive results. For example, in the Arkhangelsk area, where the population had been in decline in 2007, 12634 live births were recorded, 771 more than in 2006. In the hospitals in the area, 55 new units of diagnostic equipment had been provided .

Realization of the aims of the above-mentioned Concept from 1993 in Russia would have been impossible without the involvement of both national and international experts. It is paradoxical, therefore, that on the one hand, the system of social help had already essentially been developed in Russia during the Soviet period. But in the 1990s, the period in which reform was taking place, the direction of its further development was not yet absolutely clear. Given this, the theoretical and practical experiences of Norway, which had already suffered the test of time, were interesting and important.

On the other hand, the establishment of intercultural interaction between the social organizations, funds and institutes of the two neighbouring countries was not less significant for the possibility of rendering help to Russia. Norway has not only appeared as one of the 
best providers of assistance to the Russian north, through its reorganization of the social help provided, but it has also promoted the integration of Russia into the international community.

Table 5: Main educational institutions and the faculties offering social work training in North-West Russia (19912007)

\begin{tabular}{|c|c|c|c|c|}
\hline Institution & Place & Year of opening & $\begin{array}{l}\text { Number of } \\
\text { students (2007) }\end{array}$ & $\begin{array}{l}\text { Total number of } \\
\text { graduates }\end{array}$ \\
\hline Northern State Medical University & Arkhangelsk & 1991 & About 450 & About 1200 \\
\hline Pomor State University & Arkhangelsk & 1996 & About 340 & About 750 \\
\hline $\begin{array}{l}\text { Murmansk State Technical } \\
\text { University }\end{array}$ & Murmansk & 1999 & About 125 & About 80 \\
\hline Petrozavodsk State University & Petrozavodsk & 1999 & About 130 & About 85 \\
\hline $\begin{array}{l}\text { Petrozsavodsk Pedagogical } \\
\text { University }\end{array}$ & Petrozavodsk & 2000 & About 130 & About 60 \\
\hline $\begin{array}{l}\text { Sankt- Petersburg State Institute } \\
\text { of psychology and social work }\end{array}$ & $\begin{array}{l}\text { Sankt- } \\
\text { Petersburg }\end{array}$ & 1995 & About 450 & About 200 \\
\hline $\begin{array}{l}\text { Sankt- Petersburg State } \\
\text { University }\end{array}$ & \begin{tabular}{|l} 
Sankt- \\
Petersburg
\end{tabular} & 1997 & About 160 & About 170 \\
\hline $\begin{array}{l}\text { The 'Gerzen' State Pedagogical } \\
\text { University }\end{array}$ & $\begin{array}{l}\text { Sankt- } \\
\text { Petersburg }\end{array}$ & 1997 & About 160 & About 170 \\
\hline Total & & & About 1940 & About 2700 \\
\hline
\end{tabular}

The paramount importance of the role taken on by Norway in the formation of the Barents EuroArctic Region in 1993 has accelerated the establishment of cooperation between adjoining territories in the field of social activity.

The meaning of Norwegian-Russian social projects (in the period 1990 to about 2000) for Russia is:

- Financial and organizational support and organization for the mutually conducted and including setting-up 150 projects ;

- Participation in contributions to train over 1500 social workers and teachers of social work in higher education ;

- Stimulation of the internal analysis and the study of the international experience within Russian social institutions, including services.

- Stimulation of the practical activity of the social services and non-governmental organizations on a municipal level.

There can be little doubt that the bilateral social projects that existed between Norway and Russia helped to stimulate knowledge between them about each other's social systems. Besides, the projects that have appeared are highly relevant as they have obviously not only helped Norway to get to know its Russian neighbour again, but have also assisted in the organization of social work in the Russian north, including the opening of new establishments, and raising the qualifications of those engaged in social work.

\section{Main educational institutions and the faculties offering social work training in North-West Russia (1991-2007)}

In the north of Russia in 1995-2007, international projects have strengthened the partnership between hospitals and the social services, improving the care of persons with limited capacity 
and making the running of these services more efficient.

Recently, Sweden has chosen to withdraw from the sphere of social cooperation with Russia, preferring to concentrate on the provision of support to other states. This is regrettable if one recollects the long-term, interaction which took place over almost a century between these states, despite the complexities in their relations. Continued contact tends to help to improve understanding at all times.

Norway continues to co-operate actively, and this is especially apparent in the north. Certainly, there are difficulties, partly because of the historical background, but also because little understanding has been arrived at of the features of different periods of development, or indeed of the mentality of both of the countries. On the other hand, however, there has been little comparative interdisciplinary and intercultural analysis of the theory and practice of the social help conducted, including forms of professional training. This remains to be done and it will be the ensuing knowledge becomes more readily available to specialists and public alike. Meanwhile, only the historically used socially focused approach is capable of promoting stability in relations between the states.

The meaning of Norwegian-Russian social projects (in the period 1990 to the early 2000s) from a Norwegian perspective is:

- Development of new steps in the relations between two neighboring states in the postSoviet period;

- The creation of an atmosphere of greater understanding and friendly interest in one an other;

- Promoting a more stable and secure international situation;

- Obtaining clearer and more reliable information about the historical experience and everyday situation in Russia in the present day.

Historical links, a common border and a general aspiration to interact has led to better understanding between Russia and Norway, and has affected the intensity of the contacts in the north during recent years, especially in comparison with the contacts with other neighbouring territories. Russia and Norway have collected a wide range of experience about the decisionmaking relevant to social problems, and their common experiences unite to form such an extensive record that it is not far from comprising the most essential aspects required for the formation of a model of social help.

Experience of the integration of social work activity in the Russian and Norwegian north is useful, and enables a perspective to be built up. At the beginning of the 21st century, a transformation in the social policy can be seen that not only includes mutually advantageous collaborations, but also more partnerships. Today, through joint effort, we know and understand each other better, which is satisfying in the light of the minimal and frequently complete absence of information on the organization of social help in the early nineties. Now comes a stage of serious research and reflection on the experience of the northern territories, and on the interaction between the two countries.

\section{Conclusion}

Certainly, it is impossible to deny that, in Russia, throughout the 19th and 20th centuries, there were problems with the definition of even the most comprehensible concept of social policy, the systematizing of the state and public institutes of assistance, and the organization of finance and management. However, it is interesting to note that these questions also excited attention in Norway. Meanwhile, despite the complexities, both Russia and Norway, developed a philanthropic sphere that evolved from national traditions, and historical conditions during the previous 160-170 years. 
Russia was not an exception among the European states, it is a normal country where the evolutionary development of social policy continued as it did in other places. But the pace of this development was different, sometimes slower and sometimes faster, but nevertheless evident. At the same time, we should underline that, in Russia, the social policy suffered because the tragedies, dramas and contradictions in the political, economical and social spheres were played out in history to a more extreme degree than in Norway. As a result of this, it is probable that Russia needs more time to improve and develop its social care system. In particular, some additional factors can be addressed in the future, using past experience as a basis for influencing the modernization of social policy at macro and micro levels. On the macro level, there are certain requirements:

- A long, stable period of time in which changes can take place;

- Stimulation of stable changes in the relationship between the government and society to solve the social problems of the poor and the needs of orphans, families with a low income and others through systemic change;

- Qualified reforms on the back of clever legislation;

- Improving citizens' knowledge of the aims of the reforms;

- Preparation of citizens for the more individual social care (for the most needy individuals) and the adoption of a pragmatic approach to the organization of social policy that can change people's outlook.

None of this is particularly easy to realize where social policy is concerned, and it could be possible that it might only be achieved in a couple or a few generations. If we look at Norway, we can understand that, on the whole, Norway had a stable period over the last 100 years that made it possible to address most of the problems that Russia has to deal with now. There is a need to consider social policy from the point of view of the possibilities for interaction between Russia and Norway in this sphere, because this can strengthen the bond between the countries and encourage stability. At the micro level, what is required is:

- $\quad$ Further development of social work as a profession and a sphere of activity;

- $\quad$ The creation of innovative social services that can expand through the implementation of new methods and models of working for the provision of social assistance;

- $\quad$ Formation of active national associations in the regions;

- Active cooperation between the government and the organizations, between organizations, such as the International Association of Social Work Schools and other international organizations on a regional level.

The versatility of social problems and the ways that political decisions are reached in the history of Russia and Norway prove the importance of the well-defined social orientation of the governments, departments and the charitable societies. If Norway and Russia follow this position, the transformation of the social support to take into account the interests of people will have been fulfilled, meaning that life in a welfare society has been successful.

Seip, A. L. Motive Forces behind the New Social Policy after 1870. Norway on the European Scene, Scandinavian Journal of History, 1984, 9.

Kuhnle, S. (1994) Historisk oversikt in Kuhnle S. \& Solheim L. Velferdsstaten vekst og omstilling, Oslo: Tano; Hatland, A. \& Kuhnle S. \& Romøren T.I. (1996) Den norske velferdsstaten, Oslo: Ad Notam Gyldendal.

Zhbankov, D.N. (1895) A few comments on the public social welfare project [Neskolko zametok po povodu proekta obshchestvennogo prizreniia], Sankt-Petersburg, 8.

Works of the Commission for Reviewing Legislation on Social Care [Trudy Komissii po peresmotru zakonodatelstva ob obshchestvennom prizrenii] (1892-1896), Sankt-Petersburg, 10-15.

The common schools, and compulsory education in Norway: In: International Congress of Charities, Correction and Philanthropy (1862), London, V.2, P. 204-218.

4 e Congresso internazionale d'assistenza pubblica e private (Congres international d'assistance publique et privee (4th)), Milano, 23-27 May 1906 (1906), Milan; Aderkas, O.K. (1906) IV 
International Congress on the Questions of Public and Private Care in Milan [Vedomstvo detskix priyutov i ego zadachi. Chetvertyi Mezhdunarodnyj Kongress po Voprosam Obshchestvennogo i Chastnogo Prizrenija v Milane], P. XXVII (Sankt-Peterburg).

Recueil des travaux du V Congres international d'assistance publique et privee a Copenhague, 9-13 August 1911 (International Congress on Charities, Assistance and Philanthropy) (1911), Copenhagen.

Swedish Poor Laws and Charities: A publication dedicated to the International Congress on Poor Law Relief and Charity held at Copenhagen in 1910 by the Swedish Poor Law Reform Association (Svenska fattigvårdsforbundet) (1910), Stockholm; L'Assistance francaise: Expose general de la constitution et des resultats des divers services, etablissements et oeuvres assistance ou de bienfaisance de la France. Congres international de Copenhague par Paul Strauss (1910), Paris; The collection of materials about public and private assistance in Russia (Sbornik svedenii ob obshestvennom i chactnom prizrenii v Rossii) (1910), Sankt-Peterburg etc.

Estimations made by the author on the basis of: GARF (State Archive of the Russian Federation), f. 640 , op. 1, d. 23; Ibid., op. 2, d. 345, I.12-13; Ibid., f. 109, op. 23, d.45, I.78-79; Ibid., op. 46, d. 9, I.43-45; Ibid., d. 1214, I.23; Ibid., d. 1023, I.12-13; Ibid., d. 1767, I.34-35; f. 1813 , op. 1, d. 28, I. 89-90.

Brauns, H.J. \& Kramer, D. (ed.) (1988) Social work education in Europe: A comprehensive description of social work education in 21 European countries: Deutsche Verein für Offentliche und Private Fürsorge (Frankfurt), 425.

Seip, A. L. (1984) Sosialhjelpstaten blir til. Norsk sosialpolitikk 1740-1920, Oslo: Gyldendal.

Hoffman D. L. (2003) Stalinist values. The Cultural Norms of Soviet Modernity (1917-1941). Ithaca and London: Cornell University Press, 7-10; Kotkin S. (1995) Magnetic Mountains. Stalinism as a Civilization. University of California Presss, 18-21.

The calculation has been made using: Report from different universities in Russia; Bosharova V.G., Filonov G.N. (ed.) (1998) Social work education in Russia: programs and technologies [Obuchenie socialnoj rabote v Rossii], Part 2, Moscow; Tevlina, V.V. (2002) Social work education in Russia: history, tendencies, experience, [Obrasovaie $v$ oblasti socialnoj raboty v Rossii: istorija, tendensii, opyt], Arkhangelsk, NSMU Press etc.

Materials of the commission for a methodical study of the Russian universities in the field of social work in 1998-2000) [Materialy zasedanij Soveta YMO vuzov Rossii v oblasti socialnoj raboty za 1998-2000], (2001), Moscow.

Hutchinson, G.S., Lund L. \& Oltedal S. (2001) Social Work in Norway. In: Social work in five countries. Professional education and social policy context for social work in Australia, Canada, Norway, Russia and USA, HBO-report, 25/2001, 121.

Final report about the realisation of the national project "Health Care" in the Arkhangelsk region in 2007 [Itogovyj otchet o xode natsionalnogo proekta "Zdravooxranenie" v arxangelskoj oblasti v 2007 godu], (unpublished).

Integration of the Russian North to form an international system of social work and social work education in the 1990s and the early years of 2000s (2006). In: The Materials of the scientific conference "International Cooperation on the North of Russia in the Epoch of Globalization" Arkhangelsk, 19-21 May 2005, Barents Journal, N 1(4), 51-56.

The data is calculated from the diverse collection of reports of the Social Welfare Department of the universities, the Ministry of Education and Science etc. in Russia in 1995-2007. 